\title{
Ewolucja opodatkowania dochodów osób duchownych
}

\author{
Rafał Jurowiec \\ Uniwersytet w Białymstoku \\ rafalj@o2.pl
}

Rafał Jurowiec, Evolution of levying a tax on incomes of clergy, Elpis, 16 2014: 215-220.

\begin{abstract}
This study aims to bring the system of taxation of the clergy in Poland. It presents the evolution of the taxation of the clergy in the period since World War II to the present day. In addition, it illustrates the possible legally stipulated ways of calculating income tax for the clergy, and paying particular attention to the most popular choice by the clergy - the quarterly payment of a lump sum tax on their income and the rates and procedure prescribed for this form of taxation.
\end{abstract}

\begin{abstract}
Streszczenie: Niniejsze opracowania ma na celu przybliżenie systemu opodatkowania osób duchownych w Polsce. Przedstawia ewolucję opodatkowania duchownych w okresie od II wojny światowej po dzień dzisiejszy. Ponadto ilustruje przewidziane prawem możliwości rozliczania się osób duchownych ze swego dochodu z fiskusem, zwracając szczególną uwagę na najbardziej popularne rozwiązanie wybierane przez duchownych- uiszczanie kwartalnego podatku w formie ryczałtu od dochodów osób duchownych, stawki i procedurę przewidziane dla tej formy opodatkowania.
\end{abstract}

Keywords: taxation of the clergy, lump sum tax on the income of the clergy

Słowa kluczowe: opodatkowanie dochodu duchownych, zryczałtowany podatek dochodowy od przychodu osiąganego przez osoby duchowne

W ostatnim czasie często słyszymy w licznych wypowiedziach medialnych i społecznych opinię, że duchowni nie płacą podatków i są traktowani ponad stan obowiązującego prawa daninowego. Jest to błędne twierdzenie ponieważ system opodatkowania osób duchownych w naszym kraju ma bogatą historię i różnorodny charakter. Opodatkowaniu podlegają zarówno kościelne osoby prawne oraz duchowieństwo. Niniejsze opracowanie ma na celu przybliżenie sposobów opodatkowania osób duchownych.

\section{Zarys historyczny}

W pierwszych latach po II wojnie światowej duchowni podlegali opodatkowaniu na podstawie Dekretu „o podatku dochodowym" z 1946 r. ${ }^{1}$ Wówczas na podstawie art.1 - duchowni podlegali obowiązkowi podatkowemu na równi ze wszystkimi osobami fizycznymi, które miały na obszarze Rzeczypospolitej Polskiej miejsce zamieszkania lub miejsce pobytu. Obowiązek podatkowy miał nieograniczony charakter i obejmował dochód „ze wszystkich źródeł bez względu na miejsce ich położenia”. ${ }^{2} \mathrm{~W}$ owym czasie istotnym zwolnieniem dla stanu duchownego było wynikające $\mathrm{z}$ art. 13 pkt 2 tegoż dekretu zwolnienie od podatku „przychodów na pokrycie kosztów utrzymania, otrzymanych od zamieszkałych na obszarze Rzeczpospolitej Polski osób fizycznych". Opodatkowaniu podlegał dochód przekraczający 72.000 złotych osiągnięty w ciągu roku podatkowego, natomiast skala podatkowa miała rozbudowany charakter

\footnotetext{
1 Dekret o podatku dochodowym z dnia 8 stycznia 1946 r. (Dz.U. z 1947 nr 25 poz.99).

2 Art. 3 Dekretu o podatku dochodowym z 1946 r.
}

i oscylowała w granicach od $2 \%$ do $50 \%$ przy dochodach przekraczających $4.200 .000 \mathrm{zł}$ rocznie. ${ }^{3}$ Uregulowania podatkowe zawarte w przytaczanym dekrecie były niewątpliwie niekorzystne dla duchowieństwa tradycyjnie pozostającego w celibacie, ponieważ w przypadku „osób nieżonatych lub niezamężnych powyżej 21 roku życia oraz nie mających na utrzymaniu dzieci i osiągających dochód powyżej $120.000 \mathrm{zł}$ rocznie podatek obliczany $\mathrm{w}$ skali $\mathrm{z}$ art. 18 był podnoszony o 20\%". 4 Ponadto, na mocy rozporządzenia od lipca 1949 r., Ministerstwo Skarbu wprowadziło obowiązek prowadzenia ksiąg podatkowych, co było niewątpliwie niekorzystne dla osób duchownych, zgodnie z którym duchowni wszystkich związków religijnych, świeccy i zakonni, którzy osiągają przychody w związku z zaspakajaniem potrzeb religijnych przez wykonywanie obrzędów, czynności duszpasterskich i posług religijnych lub przyjmują jakiekolwiek opłaty, ofiary i datki ze względu na swój charakter duchownego, obowiązani są prowadzić księgę podatkową. ${ }^{5}$ Jednakże, wpisowi do księgi podatkowej nie podlegały wynagrodzenia podlegające podatkowi od wynagrodzen. ${ }^{6}$

Istotną datą związaną $\mathrm{z}$ opodatkowaniem osób duchownych był rok 1957, kiedy to Ministerstwo Finansów w swych propozycjach przygotowało kilka nowych zasad opodatkowania. Wprowadzono wówczas możliwość rozliczania duchowieństwa $\mathrm{z}$ tytułu wykonywanych funkcji duszpasterskich $\mathrm{w}$ formie ryczałtu oraz zrezygnowano $\mathrm{z}$ obowiązku prowadzenia ksiąg podatkowych. Zgodnie $\mathrm{z}$ wytycznymi zawartymi w Zarządzeniu Ministra Finan-

\footnotetext{
3 Art. 18 pkt. 1 Dekretu o podatku dochodowym z 1946 r.

4 Art. 22 pkt. 1 Dekretu o podatku dochodowym z 1946 r.

5 \$2 Rozporządzenia Ministra Skarbu z dnia 5 lipca 1949 r., „o obowiązku prowadzenia ksiąg podatkowych przez duchownych".

${ }^{6} \S 3$ tegoż rozporządzenia.
} 
sów z dnia 5 czerwca 1957 r. w sprawie opodatkowania duchownych- wysokość ryczałtu zależała od pełnionej funkcji (proboszcz, wikariusz), liczby mieszkańców w danej parafii, jak również położenia samej parafii - inna stawka odnosiła się do parafii wiejskich i małych miast, miast powiatowych oraz miast wojewódzkich. Ponadto duchowni, na mocy wydanego przez Ministerstwo Finansów okólnika, zobligowało duchownych do składania deklaracji. ${ }^{7} \mathrm{~W}$ roku 1959, Ministerstwo Finansów podjęło kontrowersyjną decyzję o drastycznym podniesieniu stawek ryczałtu dla księży (70-100\%) - co spotkało się z negatywną reakcją duchowieństwa wyrażającą się m.in. w sprzeciwianiu się ustalaniu dochodów w drodze oszacowania dochodów w danych parafiach. Warto zaznaczyć, że w tym czasie żadna inna grupa zawodowa nie została objęta podwyżką podatków.

Kolejne lata nie przyniosły większych zmian w sposobie opodatkowania osób duchownych. Warto jednak nadmienić, iż w roku 1960, Ministerstwo Finansów w swych wyjaśnieniach dotyczących opodatkowania osób duchownych odniosło się do przychodów osób duchownych, niebędących proboszczami, wikariuszami bądź „,rektorami” kościołów oraz przychodów osób zakonnych osiąganych z misji, rekolekcji, intencji mszalnych bądź innych posług religijnych- te przychody zostały zakwalifikowane do przychodów podlegających opodatkowaniu na zasadach ogólnych. Uregulowania te odnosiły się również do osób duchownych i zakonnych, a także biskupów zatrudnionych w urzędach kurialnych lub innych jednostkach kościelnych. Warto w tym miejscu zwrócić również uwagę na sytuację osób stanu zakonnego, mianowicie jeżeli zakonnicy byli oddelegowani przez swoich przełożonych, bądź mianowani przez biskupów do sprawowania zarządu parafią- czyli pełnienia funkcji proboszcza, bądź też do funkcji pomocniczych jako wikariusz i w całości swoje wynagrodzenie odprowadzali do kasy domu zakonnego, nie podlegali wówczas odrębnemu opodatkowaniu. W przypadku gdy korzyści osiągnięte przez zakonnika jako proboszcza (wikariusza) parafii tylko częściowo były przekazywane do domu zakonnego, należało go traktować jak „standardowego" proboszcza lub wikariusza i ustalać zobowiązanie podatkowe według zasad ich obowiązujących. W takiej sytuacji odprowadzana przez zakonnika część przychodu do kasy zakonnej była przychodem domu zakonnego i rozliczana była jako przychód zakonu, niezależnie od opodatkowania pozostałej części jako dochodu osoby fizycznej, objętej formą opodatkowania przewidzianej osobom duchownym. ${ }^{8}$

Instrumenty finansowo- podatkowe stosowane wobec duchowieństwa w okresie drugiej połowy ubiegłego wieku miały z zasady charakter iście kontrolny i zdominowane były przez system polityczny. Instytucje religijne w owym, jakże burzliwym czasie były niejako jedynymi niezależnymi instytucjami szerokiego, społecznego zasięgu, co nie wpływało korzystnie na relacje polityczne w ich kierunku

Okólnik Ministerstwa Finansów nr PO 23/57 z dnia 9 października 1957, dot. „zgłaszania przez duchownych obowiązku podatkowego w podatku dochodowym" (Dz.Urz. Min. Fin. Nr 9, poz.31).

8 Tyrakowski M., „Opodatkowanie Kościoła Katolickiego w Polsce”, s. 73, Dom Wydawniczy ABC, Warszawa 2005. ze strony układu sił politycznych. Aparat państwowy pod pozorem kontroli dochodów osób duchownych różnych związków wyznaniowych de facto próbował nadzorować i wywierać wpływ na działalność tych instytucji.

\section{Współczesność}

Charakteryzując możliwości rozliczenia się z podatku dochodowego duchowieństwa na wstępie należy wyjaśnić kim jest osoba duchowna?

Otóż w obowiązującym systemie prawnym nie mamy jasnej, jednolitej, powszechnie obowiązującej definicji „osoby duchownej”. W przepisach często pojawia się określenie duchowieństwo, duchowny jednak jego znaczenie może być traktowane w odmienny sposób w zależności od kontekstu i instytucji na potrzeby której charakteryzujemy ten termin.

Zgodnie $\mathrm{z}$ art. $\mathrm{z}$ art. 12. ustawy „o gwarancjach wolności sumienia i wyznania" ${ }^{\prime \prime}$ duchowni oraz osoby zakonne kościołów i innych związków wyznaniowych, ustanowione według przepisów prawa wewnętrznego kościoła lub innego związku wyznaniowego, korzystają z praw i podlegają obowiązkom na równi z innymi obywatelami we wszystkich dziedzinach życia państwowego, politycznego, gospodarczego, społecznego i kulturalnego. Są oni w ramach obowiązujących przepisów ustaw zwolnieni z obowiązków niemożliwych do pogodzenia z pełnieniem funkcji duchownego lub osoby zakonnej - m.in. odbywanie zasadniczej służby wojskowej. Natomiast art. 32 ust.2 pkt, tejże ustawy stanowi, że statut kościoła lub związku wyznaniowego mającego prawnie uregulowany status w państwie, powinien określać sposób powoływania, odwoływania oraz kompetencje osób duchownych - o ile w ogóle kościół lub inny związek wyznaniowy przewiduje tworzenie takich stanowisk. ${ }^{10}$

Ponadto, zgodnie z Uchwałą Sądu Najwyższego w składzie 7 sędziów z dnia 6 maja 1992r. - duchownym w rozumieniu art. 47 ust. 1 ustawy z dnia 21 listopada $1967 \mathrm{r}$. o powszechnym obowiązku obrony Rzeczypospolitej Polskiej (Dz. U. z 1992 r. Nr 4, poz. 16), jest osoba należąca do Kościoła Katolickiego lub innego Kościoła albo związku wyznaniowego, który wyróżnia się spośród ogółu wyznawców danej religii tym, że powołana została do stałego organizowania i sprawowania kultu religijnego. Za duchownego w rozumieniu tego przepisu nie może więc być uznany każdy członek Towarzystwa Biblijnego i Traktatowego - Zarejestrowany Związek Wyznania Świadków Jehowy w Polsce - lecz tylko ten, który odpowiada kryteriom określonym jak wyżej. ${ }^{11}$

Wyznanie prawnie uznane to takie, którego stosunki z Rzeczpospolitą Polską zostały uregulowane umową międzynarodową, ustawą albo innym powszechnie obowiązującym aktem prawnym - np. ustawa o stosunku Państwa do Polskiego Autokefalicznego Kościoła Prawosławnego.

\footnotetext{
Ustawa z dnia 17 maja 1989r., „o gwarancjach wolności sumienia i wyznania”, Dz.U.2005.231.1965.

10 Tamże.

11 Uchwała Sądu Najwyższego z dnia 6 maja 1992 r., sygn. I KZP 1/92.
} 
Podsumowując ten wątek należy stwierdzić, że duchownym może być wyłącznie osoba fizyczna, która została duchownym kościoła lub związku wyznaniowego o uregulowanej sytuacji prawnej, według zasad i praktyk przyjętych przez dane wyznanie zgodnie z jej wewnętrznymi „kanonami”.

\section{Obowiązujące regulacje opodat- kowania osób duchownych.}

Duchowni mogą skorzystać z kilku rozwiązań dotyczących rozliczenia $\mathrm{z}$ należności publicznoprawnych $\mathrm{z}$ tytułu osiąganego przychodu. Kryterium decydującym o formie rozliczenia jest przede wszystkim źródło przychodu. Najpopularniejszym obok rozliczania się z osiąganego przychodu na zasadach ogólnych ( $\mathrm{w}$ ramach przychodów nie związanych bezpośrednio ze sprawowaniem funkcji duchownego - np. nauczyciela) jest rozliczenie zryczałtowanym podatkiem dochodowym od osób duchownych.

Aktualnie duchowni, aktywnie funkcjonują $\mathrm{w}$ życiu społecznym pełniąc rozmaite funkcje, pośrednio bądź też w ogóle nie związane z działalnością duszpasterską. Przeważnie ta aktywność przejawia się pracą w ramach jednostek kościelnych- kuriach diecezjalnych, seminariach duchownych, czy też jako katecheci, nauczyciele etyki, wykładowcy różnego rodzaju uczelni kościelnych i świeckich, pracując jako kapelani szpitalni lub instytucji państwowych i wojskowych czy też zarabiając w różnego rodzaju instytucjach gospodarczych, mediach oraz na typowo świeckich stanowiskach $^{12}$. Takich duchownych łączy co do zasady stosunek pracy i są oni rozliczani na zasadach ogólnych odprowadzając do budżetu państwa podatek od dochodów osób fizycznych. Opodatkowaniu na zasadach ogólnych podlegają również duchowni osiągający dochody z umów zlecenia, o dzieło czy też kontraktów menedżerskich. ${ }^{13} \mathrm{Dla}-$ tego też najogólniej rzecz ujmując, gdy osoby duchowne osiągają przychody w przypadkach innych niż związane $\mathrm{z}$ pełnieniem funkcji duszpasterskich, opłacają oni podatki na ogólnie obowiązujących zasadach ${ }^{14}$.

\section{Opodatkowanie dochodów osób duchownych $\mathrm{z}$ działalności dusz- pasterskiej.}

Duchowni, prawnie działających w Polsce wyznań oraz związków religijnych utrzymują się przeważnie z działalności duszpasterskiej. Opodatkowanie tej działalności może przybierać dwie formy. Może to być opodatkowanie dochodów z działalności duszpasterskiej osób duchownych na

M. Tyrakowski, „Opodatkowanie dochodów kościoła katolickiego w Polsce", str. 157.

13 Tamże, s. 158.

14 L. Etel, „Czy kościoły i księża płacą w Polsce podatki?”, Przegląd Podatkowy" 2002, nr 6, s. 22 zasadach ogólnych bądź w sposób „uproszczony”, czyli na zasadzie płacenia podatku dochodowego od przychodów osób duchownych w formie zryczałtowanej.

Pierwsza $\mathrm{z}$ form opodatkowania jest stosowana zdecydowanie rzadziej, ponieważ wiąże się ona po pierwsze z obowiązkiem prowadzenia podatkowej księgi przychodów i rozchodów oraz zrzeczenia się opodatkowania w formie ryczałtu za dany rok podatkowy, nie później niż do 20 stycznia roku poprzedzającego rok podatkowy, lub do dnia poprzedzającego dzień rozpoczęcia pełnienia funkcji o charakterze duszpasterskim w przypadku gdy są rozpoczęte w ciągu roku podatkowego ${ }^{15}$ Duchowni mogą również zrzec się opodatkowania w formie zryczałtowanej w ciągu 14 dni od otrzymania decyzji ustalającej wysokość podatku zryczałtowanego , zawiadamiając o tym na piśmie właściwy Urząd Skarbowy. ${ }^{16}$ Opodatkowanie dochodów z działalności duszpasterskiej na zasadach ogólnych ma też swoje plusy, ponieważ opodatkowanie na zasadach ogólnych jest ucieczką przed narzuconym $\mathrm{z}$ góry podatkiem wyliczonym $\mathrm{w}$ ramach ryczałtu, a co za tym idzie są możliwością uiszczania podatku od rzeczywiście otrzymanych dochodów, jak również wykazania kosztów uzyskania przychodu. Duchowni decydują się na wybór tej formy opodatkowania przede wszystkim z powodu małej liczby mieszkańców w danej parafii. Po drugie, dużą rolę odgrywa w tym wypadku zróżnicowanie sytuacji ekonomicznej poszczególnych regionów i środowisk, jak również fakt ogólnego zubożenia społeczeństwa. Kolejnym czynnikiem jest zmieniająca się struktura populacji wierzących i związane $\mathrm{z}$ tym uczestnictwo w praktykach religijnych- $\mathrm{w}$ sytuacji gdy w parafiach o dużej liczbie mieszkańców liczba praktykujących jest niewielka, fakt ten nie jest uwzględniany przy wymiarze podatku $\mathrm{w}$ formie ryczałtowej. Wreszcie decyduje o tym struktura duchowieństwa niosaca posługe w danej parafii- np. gdy w dużej parafii posługę niesie kilku duchownych a odsetek praktykujących jest niewielki w porównaniu z liczbą mieszkańców. Ten fakt powoduje trudności z codziennym utrzymaniem zarówno samej parafii, jak też jej duchownych. ${ }^{17}$ Podsumowując- zrzeczenie się opodatkowania w formie zryczałtowanej oznacza konieczność opłacania za dany rok podatkowy podatku dochodowego od osób fizycznych na ogólnych zasadach wynikających z ustawy o podatku dochodowym od osób fizycznych.

\section{Zryczałtowany podatek od dochodów duchownych z działalności duszpasterskiej.}

Jest to najbardziej powszechna metoda rozliczania się z fiskusem $\mathrm{z}$ dochodów osiąganych przez osoby duchow-

15 L. Etel, R. Dowgier, G. Liszewski, M. Popławski, S. Presnarowicz, Prawo podatkowe, Difin, Warszawa 2005, s. 420-421.

16 art. 51, Ustawy z dnia 27 listopada 1998 r. „o zryczałtowanym podatku dochodowym od niektórych przychodów osiąganych przez osoby fizyczne." Dz.U.1998.144.930.

17 J. Patyk, „Opodatkowanie Kościoła Katolickiego i osób duchownych”, s. $250-251$. 
ne. Jak sama nazwa wskazuje podmiotem tego podatku jest osoba fizyczna będąca osobą duchowną.

Przedmiotem opodatkowania w zryczałtowanym podatku dochodowym od przychodów osób duchownych są wyłącznie przychody $z$ opłat otrzymywanych przez osobę duchowną $\mathrm{w}$ związku z pełnionymi przez nią funkcjami o charakterze duszpasterskim, przewidzianymi przez dany kościół lub związek wyznaniowy. ${ }^{18}$

Przyjąć należy, że przychodami tego rodzaju opłat będą datki, uiszczane przez wiernych danego kościoła lub związku wyznaniowego osobie duchownej w związku z pełnioną przez nią funkcją o charakterze duszpasterskim m.in. proboszcza parafii, wikariusza, pastora, diakona, rabina, nastawnika.

Przychody z opłat otrzymywanych w związku z pełnionymi funkcjami duszpasterskimi to wszelkiego rodzaju ofiary i darowizny za czynności wykonywane przez duchownych działających w tym charakterze, przykładowo mogą to być ofiary w związku $\mathrm{z}$ intencjami mszalnymi, otrzymywane podczas kolędy, za udzielenie sakramentów. Opodatkowanie ryczałtem dotyczy przychodów duchownych $\mathrm{z}$ opłat otrzymywanych $\mathrm{w}$ związku z pełnionymi funkcjami o charakterze duszpasterskim, zatem organ ustalając opodatkowanie w tej formie powinien w pierwszej kolejności poczynić ustalenia dotyczące spełnienia tych właśnie przesłanek, bowiem osoba, która jest osobą duchowną, lecz nie osiąga przychodów ze sprawowania funkcji duszpasterskich nie będzie podlegać temu podatkowi. ${ }^{19}$

Zgodnie $\mathrm{z}$ art. 42 ust. 2 u.z.p.d.o.f. osoby duchowne zawiadamiają właściwego naczelnika urzędu skarbowego o rozpoczęciu pełnienia funkcji o charakterze duszpasterskim w ciągu 14 dni od dnia objęcia funkcji. Przepisy ustawy nie określają wzoru takiego zawiadomienia, jak również jego formy. W związku z tym przyjmuje się, że może mieć ono zarówno charakter pisemny bądź ustny- do protokołu. Zawiadomienie powinno zawierać informację o dacie rozpoczęcia pełnienia funkcji o charakterze duszpasterskim, wskazanie osoby od której pochodzi, jej adresu - miejsca pełnienia funkcji o charakterze duszpasterskim. Takie zawiadomienie powinno być opatrzone podpisem osoby zawiadamiającej, a w przypadku protokołu również podpisem urzędnika sporządzającego protokół. ${ }^{20}$

Stawki ryczałtu od przychodów proboszczów i wikariuszy określone są zgodnie $\mathrm{z}$ art.43 ust. 1 u.z.p.d.o.f. w załącznikach nr 5 i 6 ustawy. Stawki są corocznie podwyższane w stopniu odpowiadającym wskaźnikowi wzrostu cen towarów i usług konsumpcyjnych w okresie pierwszych trzech kwartałów roku poprzedzającego rok podatkowy w stosunku do tego samego okresu roku ubiegłego, ogłaszanemu przez Prezesa Głównego Urzędu Statystycznego

\footnotetext{
18 S. Babiarz, S. Bogucki, A. Dumas, R. Pęk, S. Presnarowicz, J. Pustuł, „Ryczałty w prawie podatkowym”, s.274, Lexis Nexis, 2012.

19 Wyrok Wojewódzkiego Sądu Administracyjnego w Opolu z dnia 6 listopada 2013 r., sygn. I SA/Op 531/13.

20 A. Bartosiewicz, R. Kubacki, Ustawa o zryczałtowanym podatku dochodowym od niektórych przychodów osiąganych przez osoby fizyczne, Komentarz, Warszawa 2011 r., s.545.
}

w Dzienniku Urzędowym Rzeczypospolitej Polskiej „Monitor Polski”- art. 54 u.z.p.d.o.f.

Czynnikiem determinującym wysokość opłacanej kwartalnej stawki zryczałtowanego podatku przez osoby duchowne jest sprawowana funkcja (proboszcz, wikariusz- bądź odpowiednio do osób duchownych wszystkich wyznań, sprawujących porównywalne funkcje, np. imam) ilości mieszkańców w danej parafii.

Tabela nr 1.

Stawki obowiązujące dla proboszczów za rok 2014 zgodnie z załącznikiem nr 2 do u.z.p.d.o.f.

KWARTALNE STAWKJ RYCZAŁTU

OD PRZYCHODÓW PROBOSZCZÓW

\begin{tabular}{|c|c|c|}
\hline \multicolumn{2}{|c|}{ W parafiach o liczbie mieszkańców } & $\begin{array}{c}\text { Wysokość stawek } \\
\text { w złotych }\end{array}$ \\
\cline { 1 - 2 } powyżej & do & 420 \\
& 1000 & 477 \\
1000 & 2000 & 514 \\
2000 & 3000 & 563 \\
3000 & 4000 & 612 \\
4000 & 5000 & 669 \\
5000 & 6000 & 729 \\
6000 & 7000 & 787 \\
7000 & 8000 & 848 \\
8000 & 9000 & 921 \\
9000 & 10000 & 1002 \\
10000 & 12000 & 1087 \\
12000 & 14000 & 1183 \\
14000 & 16000 & 1281 \\
16000 & 18000 & 1386 \\
18000 & 20000 & 1502 \\
20000 & & \\
\hline
\end{tabular}

Objaśnienie: Liczbę mieszkańców przyjmuje się według stanu na dzień 31 grudnia roku poprzedzającego rok podatkowy, za który opłacany jest ryczałt, według danych właściwych organów administracji miast i gmin, prowadzących ewidencje ludności.

Tabela nr 2.

Stawki obowiązujące dla wikariuszy za rok 2014 zgodnie z załącznikiem nr 6 do u.z.p.d.o.f.

KWARTALNE STAWKI RY CZAŁTU OD PRZYCHODÓW WIKARIUSZY

\begin{tabular}{|c|c|c|c|c|}
\hline \multicolumn{2}{|c|}{$\begin{array}{l}\text { W parafiach o liczbie } \\
\text { mieszkańców }\end{array}$} & \multicolumn{3}{|c|}{ Jeżeli siedziba parafii znajduje się } \\
\hline \multirow{3}{*}{ powyżej } & \multirow{3}{*}{ do } & \multirow{2}{*}{$\begin{array}{l}\text { na terenie gminy } \\
\text { lub miasta o licz- } \\
\text { bie mieszkańców } \\
\text { do } 5000\end{array}$} & \multicolumn{2}{|c|}{$\begin{array}{l}\text { w mieście o liczbie } \\
\text { mieszkańców }\end{array}$} \\
\hline & & & $\begin{array}{c}\text { powyżej } 5000 \\
\text { do } 50000\end{array}$ & $\begin{array}{c}\text { powyżej } \\
50000\end{array}$ \\
\hline & & \multicolumn{3}{|c|}{ wysokość stawek w złotych } \\
\hline & 1000 & 127 & 264 & 380 \\
\hline 1000 & 3000 & 380 & 399 & 399 \\
\hline 3000 & 5000 & 399 & 423 & 440 \\
\hline 5000 & 8000 & 408 & 440 & 452 \\
\hline 8000 & 10000 & 423 & 462 & 475 \\
\hline 10000 & & 440 & 475 & 486 \\
\hline
\end{tabular}

Objaśnienie: Liczbę mieszkańców przyjmuje się według stanu na dzień 31 grudnia roku poprzedzającego rok podatkowy, za który opłacany jest ryczałt, według danych właściwych organów administracji miast i gmin, prowadzących ewidencje ludności. 
Analizując powyższe stawki należy nadmienić, iż Naczelnik właściwego Urzędu Skarbowego na podstawie art. 46 ust. 1 dokonuje wymiaru ryczałtu na dany rok podatkowy w formie decyzji na podstawie danych mających wpływ na wysokość.

Stawka ryczałtu ulega obniżeniu o kwotę składki na ubezpieczenie zdrowotne, opłaconej zgodnie z przepisami o świadczeniach opieki zdrowotnej, finansowanych ze środków publicznych bezpośrednio przez osobę duchowną w kwartale, za jaki uiszczany jest ryczałt, o ile składka ta nie została odliczona od podatku dochodowego. Kwota składki na ubezpieczenie zdrowotne, o którym mowa w ustawie z dnia 27 sierpnia 2004 r. o świadczeniach opieki zdrowotnej finansowanych ze środków publicznych (Dz. U. $\mathrm{Nr} 210$, poz. 2135), o którą zmniejsza się stawkę ryczałtu od przychodów osób duchownych, nie może przekroczyć 7,75\% podstawy wymiaru tej składki, określonej w odrębnych przepisach- art. 44 u.z.p.d.o.f.

Ponadto, mając na względzie art. 46 u.z.p.d.o.f., właściwy naczelnik urzędu skarbowego, na wniosek osoby duchownej, odpowiednio obniża stawki ryczałtu określone w załącznikach nr 5 i 6 , jeżeli liczba wyznawców na danym terenie stanowi mniejszość w ogólnej liczbie mieszkańców. Osoba duchowna jest obowiązana dołączyć do wniosku oświadczenie o liczbie wyznawców. W takim wypadku właściwy naczelnik urzędu skarbowego wydaje decyzję ustalającą wysokość ryczałtu, odrębnie na każdy rok podatkowy.

Budzące interpretacyjne problemy określenie „mniejszości” zostało wyjaśnione w wyroku Naczelnego Sądu Administracyjne $\mathrm{z}$ dnia 31 sierpnia 1999, o sygn. I SA/Łd 1365/97, w którym Sąd stwierdził, że mniejszość, o jakiej mowa w $\$ 4$ rozporządzenia Ministra Finansów z dnia 20 grudnia $1991 \mathrm{r}$. w sprawie opodatkowania przychodów osób duchownych (Dz. U. Nr 124, poz. 552 ze zm.), któremu odpowiada art. 46 ust. 2 obecnie obowiązującej ustawy z dnia 20 listopada 1998 r. o zryczałtowanym podatku dochodowym od niektórych przychodów osiąganych przez osoby fizyczne (Dz. U. Nr 144, poz. 930), występuje w sytuacji, gdy liczba osób danej religii (wyznania) jest mniejsza od połowy mieszkańców parafii. ${ }^{21}$

\footnotetext{
21 Wyrok Naczelnego Sądu Administracyjnego (do 2003.12.31) w Łodzi, z dnia 31 sierpnia 1999 r., sygn. I SA/Łd 1365/97.
}

Osoby duchowne opłacają ryczałt, pomniejszony o zapłaconą w kwartale składkę na ubezpieczenie zdrowotne, o którym mowa w ustawie z dnia 27 sierpnia $2004 \mathrm{r}$. o świadczeniach opieki zdrowotnej finansowanych ze środków publicznych (Dz. U. Nr 210, poz. 2135), bez wezwania - w terminie do dnia 20 następnego miesiąca po upływie kwartału, a za czwarty kwartał - do dnia 28 grudnia roku podatkowego, na rachunek urzędu skarbowego- art. 47 u.z.p.d.o.f.

Zgodnie z art. 50 u.z.p.d.o.f. osoby duchowne opłacające ryczałt są zwolnione od obowiązku składania zeznań podatkowych o wysokości osiągniętego dochodu ze źródła przychodu objętego ryczałtem. Natomiast na podatnikach tego podatku ciąży obowiązek złożenia rocznej deklaracji podatkowej, oznaczonej symbolem PIT-19A. ${ }^{22}$

Zryczałtowana forma opodatkowania przychodu osób duchownych nie wydaje się restrykcyjną formą opodatkowania $\mathrm{w}$ porównaniu $\mathrm{z}$ innymi formami ryczałtu ustawy z dnia 20 listopada 1998 r. „o zryczałtowanym podatku dochodowym od niektórych przychodów osiąganych przez osoby fizyczne". Zasady opodatkowania $\mathrm{w}$ formie ryczałtu od przychodu osób duchownych są jasne i proste, co w połączeniu z możliwością rezygnacji i wyboru opodatkowania na zasadach ogólnych sprawia, że opodatkowanie osób duchownych ma takie same cechy jak inne ryczałty. Analizując przedmiotowy ryczałt należy stwierdzić, iż duchowni tak jak każda pracująca osoba fizyczna płacą podatek od swoich przychodów jedynie z tą różnicą, że podatek ten jest opłacany w głównej mierze $\mathrm{w}$ formie kwartalnego ryczałtu. Tak więc należy stanowczo stwierdzić, iż duchowni podlegają obowiązkowi uiszczania podatku od przychodów uzyskiwanych z działalności duszpasterskiej. Co prawda niektórym stawki mogą wydawać się niezbyt wysokie, jednakże należy mieć na uwadze okoliczności, że nie są to stawki obliczone od dochodu lecz obliczone ryczałtowo bez uwzględniania wydatków ponoszonych na funkcjonowanie parafii.

\footnotetext{
22 S. Babiarz, S. Bogucki, A. Dumas, R. Pęk, S. Presnarowicz, J. Pustuł, „Ryczałty w prawie podatkowym”, s.283, Lexis Nexis, 2012.
}

\section{Bibliografia}

Babiarz S., Bogucki S., Dumas A., Pęk R., Presnarowicz S., Pustuł S., „Ryczałty w prawie podatkowym”, Lexis Nexis, Warszawa 2012

Bartosiewicz A., Kubacki R., „Ustawa o zryczałtowanym podatku dochodowym od niektórych przychodów osiąganych przez osoby fizyczne, Komentarz", ABC, Warszawa 2011 r.;

Etel L., „Czy Kościoły i księża płacą w Polsce podatki?”, Przegląd Podatkowy" 2002, nr 6;

Etel L., Dowgier R., Liszewski G., Popławski M., Presnarowicz S., „Prawo podatkowe”, Difin, Warszawa 2005,
Patyk J., „Opodatkowanie Kościoła Katolickiego i osób duchownych”, TNOIK, Toruń 2008.

Tyrakowski M., „Opodatkowanie Dochodów Kościoła Katolickiego w Polsce", Dom Wydawniczy ABC, Warszawa 2005

\section{Akty prawne:}

Dekret „o podatku dochodowym” z dnia 8 stycznia 1946 r., Dz.U. z $1947 \mathrm{nr} 25$ poz.99

Rozporządzenie Ministra Skarbu z dnia 5 lipca 1949 r. „o obo- 
wiązku prowadzenia ksiąg podatkowych przez duchownych", Dz.U. 1949 nr 40 poz. 292

Okólnik Ministerstwa Finansów nr PO 23/57 z dnia 9 października 1957, dot. „zgłaszania przez duchownych obowiązku podatkowego w podatku dochodowym”, Dz.Urz. Min. Fin. Nr 9, poz.31

Ustawa z dnia 17 maja 1989r., „o gwarancjach wolności sumienia i wyznania” Dz.U.2005.231.1965 ze zm.

Ustawa z dnia 27 listopada 1998 r. „o zryczałtowanym podatku dochodowym od niektórych przychodów osiąganych przez osoby fizyczne." Dz.U.1998.144.930 ze zm.

\section{Orzecznictwo}

Uchwała Sądu Najwyższego z dnia 6 maja 1992r., sygn. I KZP 1/92
Wyrok Naczelnego Sądu Administracyjnego (do 2003.12.31) w Łodzi, z dnia 31 sierpnia 1999 r., sygn. I SA/Łd 1365/97

Wyrok Wojewódzkiego Sądu Administracyjnego w Opolu z dnia 6 listopada 2013 r., sygn. I SA/Op 531/13

\section{Tabele}

Tabela nr 1 - załącznik nr 5 do ustawy z dnia 27 listopada 1998 r. „o zryczałtowanym podatku dochodowym od niektórych przychodów osiąganych przez osoby fizyczne." Dz.U.1998.144.930 ze zm.

Tabela nr 2 - załącznik nr 6 do ustawy z dnia 27 listopada 1998 r. „o zryczałtowanym podatku dochodowym od niektórych przychodów osiąganych przez osoby fizyczne." Dz.U.1998.144.930 ze zm. 